\title{
Viral load profiles in drug users with asymptomatic HIV infection and normal CD4 cell counts
}

\author{
Zubairi Djoerban
}

\begin{abstract}
Abstrak
Sejak tahun 2000 jumlah penderita HIV/AIDS di Indonesia meningkat tajam, terutama pada pecandu narkotika suntik. Terapi antiretroviral yang terbukti dapat menurunkan mortalitas dan meningkatkan kualitas hidup pasien, diberikan berdasarkan kondisi klinis, jumlah sel limfosit CD4 dan kadar virus dalam darah. Dalam penelitian ini dilakukan pemeriksaan kadar CD4 dan kadar virus

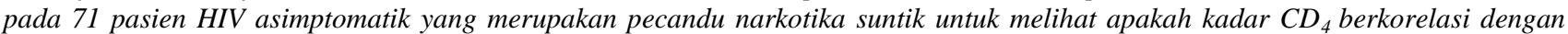
kadar virus HIV. Kadar CD4 diperiksa dengan metode imunofluoresensi indirek menggunakan antibodi monoklonal dan kadar virus menggunakan teknik PCR. Pemeriksaan hitung virus dilakukan pada 56 pasien yang mempunyai kadar CD4 lebih dari 200 sel/mm3 $\bar{x}=473 \pm 180,6)$. Sebanyak 30 orang $(55,4 \%)$ mempunyai kadar virus dalam darah lebih dari $55.000 \mathrm{kopi} / \mathrm{ml}$ dan $35,7 \% \mathrm{kadar}$ virusnya 5.000-55.000 kopi/ml. Korelasi antara kadar CD4 dengan kadar virus dalam darah memberi nilai r: 0,194. Disimpulkan bahwa pada pecandu narkotika kadar CD4 tidak berkorelasi dengan kadar HIV sehingga pemberian antiretroviral sebaiknya didasarkan pada kadar HIV dalam darah. (Med J Indones 2002; 11: 143-7)
\end{abstract}

\begin{abstract}
Since the year 2000 there has been a steep increased in the number of HIV/AIDS patients in Indonesia, coming mostly from intravenous drug users. Antiretroviral treatment has been proved to decrease mortality and increase quality of life of HIV/AIDS patients. The treatment is given according to clinical condition of the patients, number of CD4 and viral load. In this study, CD4 and viral load were examined in 71 asymptomatic HIV patients originated from injecting-drug users. CD4 counting was performed by indirect immunoflouresence method using monoclonal antibody, and viral load was tested using PCR technique. Among 56 patients who has the number of CD4 more than 200/ $\mathrm{mm}^{3}, 30$ patients $(55,4 \%$ ) has viral load more than 55,000 copies/ml and 35,7\% has viral load 5,000-55,000 copies $/ \mathrm{ml}$. Correlation between the number of CD 4 and viral load gave the r value of 0,194. It is concluded that there is no association between the number of CD 4 and viral load in drug user HIV/AIDS patients. The treatment of HIV/AIDS for these patients should be given according to the viral load. (Med J Indones 2002; 11: 143-7)
\end{abstract}

Keywords: viral load, CD4, injecting-drug user

Since the year 2000 there has been a sharp increased in the number of HIV/AIDS patients in Indonesia. It is estimated that between 80.000 and 120.000 persons are currently infected with HIV, coming mostly from intravenous drug users. ${ }^{1}$ Treatment with antiretroviral drugs (reverse-transcriptase inhibitors, protease inhibitors etc) when used as part of combination drug regimens, can profoundly suppress viral replication, with consequent repletion of CD4. The combination of anti retroviral drugs has been demonstrated to slow the

Division of Hematology-Medical Oncology, Department of Internal Medicine, Faculty of Medicine, University of Indonesia / Dr. Cipto Mangunkusumo Hospital, Jakarta, Indonesia progression of HIV type 1 (HIV-1) disease dramatically and to lower mortality among adults cases ${ }^{2}$, children and adolescents ${ }^{3}$ infected with HIV-1. Clinical trials have shown the efficacy of the highly active antiretroviral-drug combinations $s^{3,4,5,6,7,8}$ by measuring the plasma load of HIV RNA and CD4+ cell counts.

It was important to identify subgroups of HIV infections, in which the anti retroviral treatment should be started (Table 1). The first clinical cathegory is symptomatic HIV patients (wasting, prolonged fever, thrush). There was consensus that these patients should be treated with antiretroviral therapy. ${ }^{9}$ The second clinical category is HIV infected patients without clinical symptoms. Consideration for starting antiretroviral therapy in the second group is 
more complex. The risk of opportunistic infections increases markedly when CD4 cell count less than 200 per cubic millimeter and it is strongly supported that this group of patients should be offered antiretroviral therapy. ${ }^{5,9}$ There was theoretical benefit of antiretroviral therapy for patients with CD4 above 200 per cubic millimeter. The other clinical category is HIV patients with more than $350 \mathrm{CD} 4$ cells $/ \mathrm{mm} 3$ but plasma HIV RNA is more than 55,000 copies $/ \mathrm{ml}$. This group should be offered antiretroviral therapy, because the risk of progression to AIDS is very high. $^{10}$

Table 1. When to start antiretroviral therapy

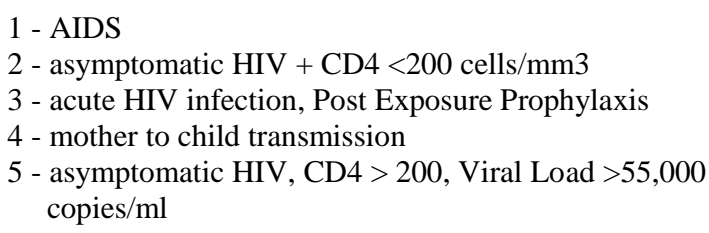

The purpose of this study was to evaluate whether there is a subgroup of asymptomatic HIV infection in drug users with normal CD4 cells count who might benefit from early antiretroviral therapy. The correlation between CD4 and viral load among drug users with normal CD4 cells count (more than 200 cells $/ \mathrm{mm}^{3}$ ) was performed in order to know whether CD4 count can be used as predictors of viral load.

\section{METHODS}

Patients with asymptomatic HIV-1 infection from drug users and having more than 200 CD4+ lymphocytes per cubic millimeter were enrolled in this study. The patients were recruited from various hospital in Jakarta between November 1999 till August 2001. CD4 and viral load were examined in 56 HIV/AIDS patients. CD4 testing was performed by indirect immunoflouresence method using monoclonal antibody, and viral load was tested using PCR technique (Amplicor HIV-1 Monitor assay version 1.5, Roche Molecular System, Branchburg NJ). All the samples for a given patient were retrieved and analyzed at the HematologyMedical Oncology Department of Internal Medicine, University of Indonesia.

\section{HIV-1 RNA PCR}

Plasma specimens were collected and stored at $-20^{\circ} \mathrm{C}$. Two hundred microlitres of each plasma samples were assayed on the same plate with three controls (negative, low positive and high positive control) in each assay. RNA was extracted from the plasma sample by the standard specimen preparation procedure, RNA is isolated directly from plasma by lysis of virus particles with a chaotropic agent followed by precipitation of the RNA with alcohol. Copy numbers of each plasma sample were calculated on the basis of the optical density readout of the final ELISA hybridization detection of amplicon and then adjusted for the efficiency of extraction, reverse trancription, and amplification of an internal target control sequence. The optical density (OD) was measured at $450 \mathrm{~nm}$. The HIV-1 RNA level is calculated according to the equation:

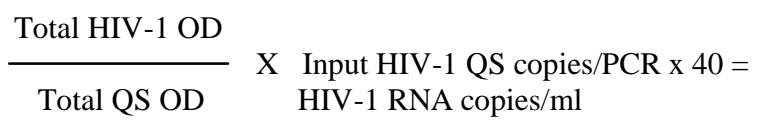

\section{Data Collection and Statistical Analysis}

The plasma HIV-1 detection range was 400-750,000 copies/ml (OD values $0.20-2.0$ ). Test results less than 400 was reported as "HIV-1 RNA not detected", less than 400 copies/ml". Test results greater than 750,000 was reported as "greater than 750,000 copies $/ \mathrm{ml}$ ". In this case, the original plasma specimen should be diluted with HIV negative human plasma and retested to know the quantitative results.

We used Spearman correlation to investigate the association between the level of CD4 count and viral load count. All data was analyzed using SPSS 10.0 for Windows.

\section{RESULTS}

Of 71 asymptomatic HIV-infected patients, 57 patients has the number of CD4 more than 200 cells $/ \mathrm{mm}^{3}$. One patient was drop out because the viral load measurement result was more than 750,000 copies $\mathrm{ml}$ and we could not repeated the test because at that time there was no reagents anymore. Among 56 patients who has the number of CD4 more than $200 / \mathrm{mm}^{3}(\mathrm{x}=473+180,6), \quad 55,4 \%(30 / 56)$ has viral load more than 55,000 copies $/ \mathrm{ml}$ and $35,7 \%$ has viral load 5,000-55,000 copies/ml (Table 2). The mean plasma HIV RNA concentration was 128,894 copies per milliliter, and the values ranged between 636- 
600,341 copies per milliliter (Table 2, Figure 1). The correlation between the number of $\mathrm{CD} 4$ and viral load gave the correlation coefficient ( $r$ value) of 0,194 and the $\mathrm{p}$ value of 0,152 (Figure 2).

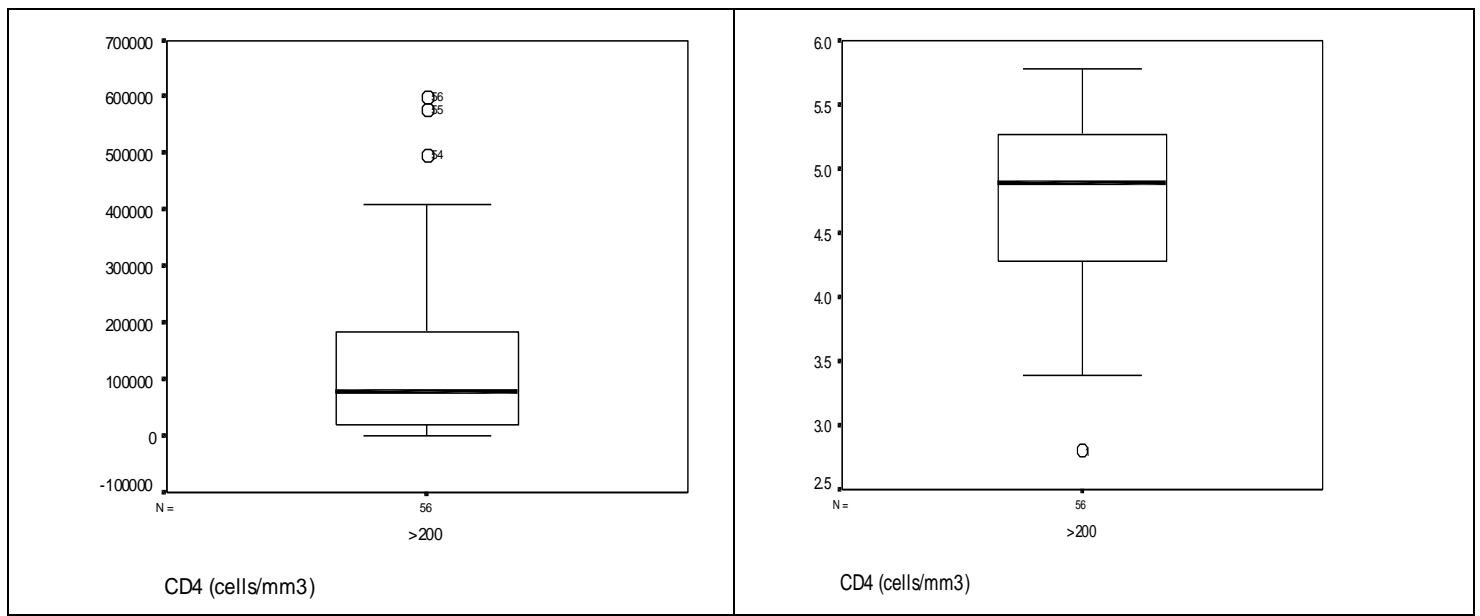

Figure 1. Distribution of plasma HIV-1 RNA in asymptomatic HIV patients with more than $200 \mathrm{CD} 4 \mathrm{cells} / \mathrm{mm}^{3}$, in copies/ml (a), log copies/ml (b)

Table 2. Viral Load in patients with more than $200 \mathrm{CD} 4$ cells $/ \mathrm{mm}^{3}$

\begin{tabular}{cccccc}
\hline No. & $\begin{array}{c}\text { Viral Load } \\
\text { (copies/ml) }\end{array}$ & $\begin{array}{c}\text { CD4 } \\
\text { (cells/mm3) }\end{array}$ & No. & $\begin{array}{c}\text { Viral Load } \\
\text { (copies/ml) }\end{array}$ & $\begin{array}{c}\text { CD4 } \\
\text { (cells/mm3) }\end{array}$ \\
\hline 1 & 636 & 276 & 29 & 76597 & 332 \\
2 & 2451 & 243 & 30 & 78344 & 382 \\
3 & 2639 & 399 & 31 & 83105 & 610 \\
4 & 3754 & 564 & 32 & 83106 & 387 \\
5 & 3981 & 441 & 33 & 89071 & 675 \\
6 & 7233 & 646 & 34 & 106882 & 250 \\
7 & 7962 & 450 & 35 & 141266 & 608 \\
8 & 9400 & 286 & 36 & 146832 & 436 \\
9 & 11439 & 397 & 37 & 153369 & 223 \\
10 & 12569 & 554 & 38 & 161600 & 303 \\
11 & 12912 & 489 & 39 & 164347 & 252 \\
12 & 15113 & 258 & 40 & 168364 & 652 \\
13 & 16381 & 390 & 41 & 172415 & 241 \\
14 & 17410 & 274 & 42 & 182021 & 940 \\
15 & 21487 & 653 & 43 & 187800 & 458 \\
16 & 23136 & 837 & 44 & 191045 & 652 \\
17 & 23406 & 364 & 45 & 228328 & 211 \\
18 & 24013 & 360 & 46 & 240877 & 535 \\
19 & 29007 & 439 & 47 & 250242 & 374 \\
20 & 33306 & 690 & 48 & 262929 & 717 \\
21 & 37649 & 297 & 49 & 275833 & 647 \\
22 & 47794 & 485 & 50 & 291507 & 675 \\
23 & 48507 & 584 & 51 & 294064 & 865 \\
24 & 53396 & 567 & 52 & 377790 & 613 \\
25 & 53854 & 522 & 53 & 410356 & 433 \\
26 & 56495 & 296 & 54 & 496988 & 327 \\
27 & 72651 & 266 & 578641 & 771 \\
28 & 75405 & 547 & 600341 & 395 \\
\hline
\end{tabular}




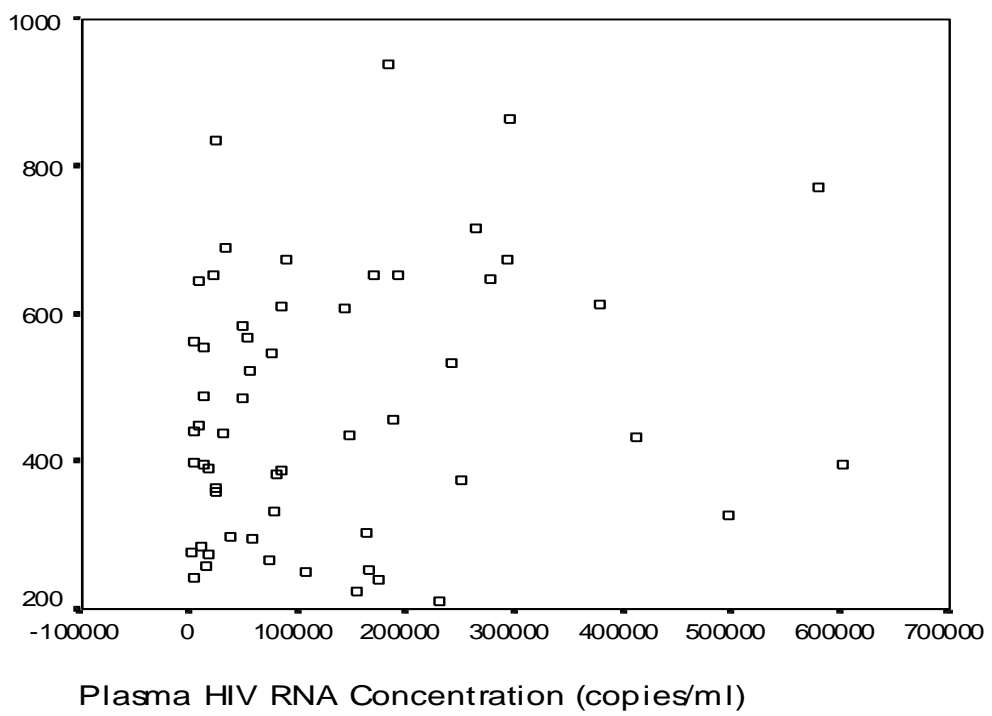

Figure 2. Correlation between the number of CD4 and Viral Load, $p=0.152, r=0,194$

\section{DISCUSSION}

Ongoing HIV replication leads to immune system damage and progression to AIDS. HIV infection is always harmful, and without treatment, true long-term survival, free of clinically significant immune dysfunction, is unusual. Plasma HIV RNA levels indicate the magnitude of HIV replication and is associated with the rate of CD4+ T cell destruction, whereas CD4+ $\mathrm{T}$ cell counts indicate the extent of HIV-induced immune damage. ${ }^{11}$

In this study, we evaluated that there was no negative correlation between plasma HIV-1 RNA viral load and CD4 cells count in drug users group. More than half of the drug users with asymptomatic HIV infection (55.4\%) with normal CD4 counts (more than 200 cells $/ \mathrm{mm}^{3}$ ) had high plasma HIV RNA level. ACTG 175, a multicenter study in HIV patients with 200-500 CD4 cells $/ \mathrm{mm}^{3}$ conducted by Lathey et al, showed that viral load was inversely corelated with CD4 cell number. ${ }^{12}$ In this multicenter study the patients were not grouped according to the way of transmission.

Previous studies showed that there were different underlying conditions in drug users group, e.g. coinfection with Hepatitis C and B virus, tuberculosis and endocarditis. These conditions might facilitate high replication of HIV by direct interaction between
2 viruses ${ }^{13}$ or secondary effects resulted from the release of cellular factors in response to infection. ${ }^{14,15}$

Understanding the contribution of virologic measurement and $\mathrm{CD}^{+}$cells count as prognostic factor of the disease is very important for determining when to start antiretroviral therapy, as well as for evaluating the outcome of antiretroviral therapy. $\mathrm{CD}^{+}$cell counts are good indicators of immune function in HIV infection. Plasma HIV-1 RNA assays (viral load assays) are useful as indicator of the prognosis of HIV infection, for indicating when asymptomatic patients should be treated and as a reference for subsequent monitoring of the virological response to therapy. ${ }^{16}$ Palella et.al showed that plasma HIV RNA levels provide more powerful predictors of risk of progression to AIDS and death than do $\mathrm{CD} 4^{+} \mathrm{T}$ cell levels; however, the combined measurement of the two values provides an even more accurate method to assess the prognosis of HIV-infected persons. ${ }^{2}$ There is a relationship between baseline HIV RNA levels, measured in a large cohort of HIV-infected adults, and their subsequent rate of $\mathrm{CD}^{+} \mathrm{T}$ cell decline. ${ }^{2}$ Progressive loss of $\mathrm{CD}^{+} \mathrm{T}$ cells is observed in all strata of baseline plasma HIV RNA concentrations, but substantially more rapid decline are seen in persons with higher baseline plasma HIV RNA level. Likewise, a clear gradient in risk for disease progression and death is seen with increasing baseline plasma HIV RNA levels. ${ }^{2,10,17}$ Regular, periodic 
measurement of plasma HIV RNA levels and $\mathrm{CD} 4{ }^{+} \mathrm{T}$ cell counts is necessary to determine the risk for disease progression in an HIV-infected person and to determine when to initiate or modify antiretroviral treatment regimens. As rates of disease progression differ among HIV-infected persons, treatment decisions should be individualized by level of risk indicated by plasma HIV RNA levels and $\mathrm{CD} 4^{+} \mathrm{T}$ cell counts.

Our study showed that majority of drug users with more than 200 CD4 cells/mm3 had high plasma HIV RNA level. Based on this fact we should offered the majority of HIV patients derived from drug users group to take antiretroviral therapy, although they still had high CD4 cells count level. We can suggest that in people living with HIV (PLWH) due to drug users, antiretroviral drugs should be started early although they have good clinical condition and had high level of $\mathrm{CD}^{+}$cells number.

Plasma HIV-1 viral load should be used to monitor the outcome of antiretroviral therapy. It had better value than CD4+ cell count in predicting the prognosis of HIV patients coming from injecting drug users. ${ }^{18}$

\section{CONCLUSION}

The management of PLWH came from drug user is different from the PLWH who had HIV from sexual transmission. The majority $(56,14 \%)$ of asymptomatic HIV patients with normal CD4 counts, had high plasma HIV RNA level. Early anti retroviral treatment is suggested in those patients. The viral load examination is very important to monitor the result of the treatment.

\section{REFERENCES}

1. Indonesian National AIDS Commission Republic of Indonesia: HIV/AIDS and other Sexually Transmitted Infections in Indonesia: Challenges and opportunities for action 2001

2. Palella FJ., Delaney KM., Moorman AC., Loveless MO., Fuhrer J, Satten GA, et al. Declining Morbidity and Mortality among Patients with Advanced Human Immunodeficiency Virus Infection. N Engl J Med 1998; 338:853-60

3. Gortmaker SL, Hughes M, Cervia J, Brady M, Johnson GM, Seage GR, et al. Effect of Combination Therapy including Protease Inhibitors on Mortality among Children and Adolescents Infected with HIV-1. N Engl J Med 2001; 345:1522-8

4. Katzenstein DA, Hammer SM, Hughes MD, Gundacker $\mathrm{H}$, Jackson JB, Fiscus S, et al. The Relation of Virologic and Immunologic Markers to Clinical Outcomes after
Nucleoside Therapy in HIV-Infected Adults with 200 to 500 CD4 Cells per Cubic Millimeter. N Engl J Med 1996; 335:1091-8

5. Hammer SM, Squires KE, Hughes MD, Grimes JM, Demeter LM, Currier JS, et al. A Controlled Trial of Two Nucleoside Analogues plus Indinavir in Persons with Human Immunodeficiency Virus Infection and CD4 Cell Counts of 200 per Cubic Millimeter or Less. N Engl J Med 1997; 337:725-33

6. Gulick RM, Mellors JW, Havlir D, Eron JJ, Gonzalez C, McMahon D, et al. Treatment with Indinavir, Zidovudine, and Lamivudine in Adults with Human Immunodeficiency Virus Infection and Prior Antiretroviral Therapy. N Engl J Med 1997; 337:734-9

7. WHO initiative on HIV/AIDS and STDs: Safe and effective use of anti retroviral treatments in adults with particular reference to resource limited settings

8. Collier AC, Coombs RW, Schoenfeld DA, Bassett RL, Timpone J, Baruch A, et al: Treatment of Human Immunodeficiency Virus Infection with Saquinavir, Zidovudine, and Zalcitabine. N Engl J Med 1996; 334:1011-8

9. Panel on Clinical Practice for the treatment of HIV infection: Guidelines for the use of antiretroviral agents in HIV infected adults and adolescents. August 13, 2001. [cited 2001 Dec 20]. Available from URL: http://www.hivatis.org

10. Arnaout RA, Lloyd AL, O'Brien TR, Goedert JJ, Leonard JM, Nowak MA. A simple relationship between viral load and survival time in HIV infection. Proc Natl Acad Sci 1999;96:11549-53.

11. MMWR: Report of the NIH Panel to Define Principles of Therapy of HIV Infection MMWR 1998;47(RR-5):1-41

12. Lathey JL, Hughes MD, Fiscus SA, Pi T, Jackson B, Rasheed $S$ et al. Variability and Prognostic Values of Virologic and CD4 Cell Measures in Human Immunodeficiency Virus Type 1- Invected Patients with 200-500 CD4 cells/mm ${ }^{3}$ (ACTG 175). J Infect Dis 1998;177:617-24.

13. Mercader M, Nickoloff BJ, Foreman KE. Induction of Human Immunodeficiency Virus 1 Replication by Human Herpesvirus 8. Arch Pathol Lab 2001;125:785-9

14. Wahl SM, Greenwell-Wild T, Peng G, Hale-Donze H, Doherty TM, Mizel D, Orenstein JM. Mycobacterium Avium Complex Augments Macrophage HIV-1 Production and Increases CCR5 expression. Proc Natl Acad Sci 1998; 95:12574-9

15. Moriuchi H, Moriuchi M, Mizell SB, Ehler LA, Fauci AS. In Vitro Reactivation of Human Immunodeficiency Virus 1 from Latently Infected, Resting $\mathrm{CD}^{+}$Cells after Bacterial Stimulation. J Infect Dis 2000;181:2041-4

16. O'Brien WA, Hartigan PA, Martin D, Esinhart J, Hill A, Benoit S, et al: Changes in Plasma HIV-1 RNA and CD4 ${ }^{+}$ Lymphocyte Counts and the Risk of Progression to AIDS, N Engl J Med 1996;334:426-43

17. Mellors JW, Muoz A, Giorgi JV, et al. Plasma viral load and $\mathrm{CD}^{+}{ }^{+}$lymphocytes as prognostic markers of HIV-1 infection. Ann Intern Med 1997;126:946-54.

18. Vlahov D, Graham N, Hoover D, Flynn C, Bartlett JG, Margolick JB et al. Prognostic Indicators for AIDS and Infectious Disease Death in HIV-Infected Injection Drug Users. JAMA 1998,279:35-40 